\title{
Cervical teratoma simulating thyroglossal cyst
}

\author{
Ramnik V Patel, ${ }^{1,2}$ Vivien McNamara, ${ }^{3}$ Paul Jackson, ${ }^{3}$ David Drake ${ }^{3}$
}

1 Department of Paediatric Urology, University College London Hospitals NHS

Foundation Trust, London, UK ${ }^{2}$ Department of Paediatric Urology, Great Ormond Street Children Hospital NHS Trust, London, UK

${ }^{3}$ Department of Paediatric Surgery, GOSH, London, UK

Correspondence to Ramnik V Patel, ramnik@doctors.org.uk
To cite: Patel RV, McNamara $V$, Jackson $P$, et al. BMJ Case Rep Published online: [please include Day Month Year] doi:10.1136/bcr-2013200671

\section{DESCRIPTION}

A 4-year-old girl was referred with a midline neck swelling, which has been visible over the last few months. It appeared after a possible viral or upper respiratory tract infection. She had a $2 \mathrm{~cm}$ diameter, spherical, smooth, non-tender cystic swelling in the midline below the hyoid cartilage. It was very mobile in a transverse direction but less mobile in a vertical direction. It apparently appeared to move upwards during deglutition but not when she protruded her tongue. An ultrasound scan confirmed a $12 \times 12 \times 7 \mathrm{~mm}$ mass of homogeneous echotexture with no vascular flow in the midline just below the level of the hyoid bone (figure 1). The mass was mobile on deglutition but not with protrusion of tongue movement. The presence and position of thyroid tissue was confirmed. At exploration, thick-walled cyst was easily separated from surrounding tissues and was not attached to the hyoid bone or the thyroid isthmus by any tract. Excised intact cyst was bisected and thick putty like material was found within the intact thick walled cyst. Postoperative period was uneventful. Histology confirmed mature cystic teratoma. Cervical midline teratoma is rare and could lead to airway obstruction in the perinatal period. ${ }^{1-3}$ It is important to differentiate them preoperatively and intraoperatively as the thyroglossal cysts needs the Sistrunk procedure involving the removal of the intact tract with the central portion of the hyoid bone as well as to prevent recurrence as the tract runs very close to the central body of the hyoid bone. Recurrence is rare; cosmesis and prognosis is excellent.

\section{Learning points}

- Cervical teratoma is strictly in the midline, superficial, thick walled, relatively freely mobile transversely and well preserved without any changes or complications.

- Thyroglossal cysts are slightly to the left of midline, deeper, thin walled, more fixed and attached to the hyoid bone and thyroid isthmus, moves with deglutition and protrusion of tongue and gets early infection.

- Ultrasound scan shows relatively homogeneous fluid in an uncomplicated thyroglossal cyst and is more thick putty-like material and sometimes may show calcification, hair like structures and heterogeneous contents in cervical teratoma. Congenital midline cervical anomalies in general and cervical teratoma in particular are essential to consider in the clinical assessment of head and neck midline masses in children.
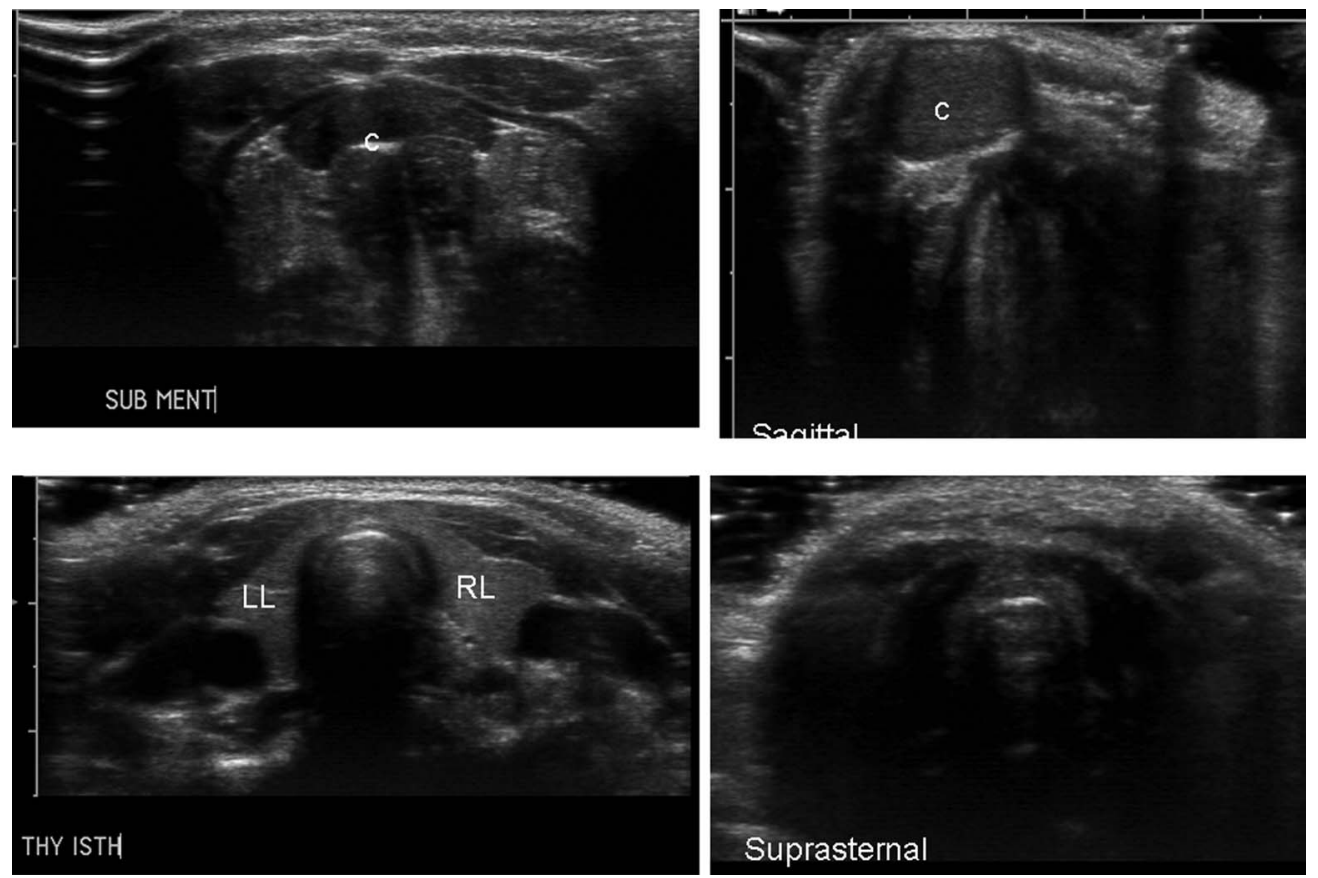

Figure 1 (A and B) Transverse and sagittal views showing thick-walled homogeneous echotexture of the cyst (C) contents. (C) Thyroid isthmus and both lobes; RL, right lobe; LL, left lobe. (D) Suprasternal area showing normal neck structures. 
Contributors All authors have actively participated in the management of this patient and in preparation, editing and critically apraising this manuscript.

Competing interests None.

Patient consent Obtained.

Provenance and peer review Not commissioned; externally peer reviewed.

\section{REFERENCES}

1 Foley DS, Fallat ME. Thyroglossal duct and other congenital midline cervical anomalies. Semin Pediatr Surg 2006;15:70-5.

2 Davenport $\mathrm{M}$. ABC of general surgery in children. Lumps and swellings of the head and neck. BMJ 1996:312:368-71.

3 LaRiviere CA, Waldhausen JHT. Congenital cervical cysts, sinuses, and fistulae in pediatric surgery. Surg Clin North Am 2012;92:583-97.

Copyright 2013 BMJ Publishing Group. All rights reserved. For permission to reuse any of this content visit http://group.bmj.com/group/rights-licensing/permissions.

BMJ Case Report Fellows may re-use this article for personal use and teaching without any further permission.

Become a Fellow of BMJ Case Reports today and you can:

- Submit as many cases as you like

- Enjoy fast sympathetic peer review and rapid publication of accepted articles

- Access all the published articles

- Re-use any of the published material for personal use and teaching without further permission

For information on Institutional Fellowships contact consortiasales@bmjgroup.com

Visit casereports.bmj.com for more articles like this and to become a Fellow 